\title{
Cervical Adenomyoma, Endometrial Type
}

National Cancer Institute

\section{Source}

National Cancer Institute. Cervical Adenomyoma, Endometrial Type. NCI Thesaurus.

Code C40233.

An adenomyoma that arises from the cervix and is characterized by the presence of

endometrial type glands and endometrial stroma, surrounded by smooth muscle. There is no evidence of atypia. 